\title{
Synergistic Exacerbation of Mitochondrial and Synaptic Dysfunction and Resultant Learning and Memory Deficit in a Mouse Model of Diabetic Alzheimer's Disease
}

\author{
Yongfu Wang ${ }^{\mathrm{a}}$, Long $\mathrm{Wu}^{\mathrm{a}}$, Jianping $\mathrm{Li}^{\mathrm{a}}{ }$, Du Fang ${ }^{\mathrm{a}}$, Changjia Zhong ${ }^{\mathrm{a}, \mathrm{b}}$, John Xi Chen ${ }^{\mathrm{c}}$, and \\ Shirley ShiDu Yan ${ }^{a}{ }^{*}$ \\ aDepartment of Pharmacology and Toxicology, and Higuchi Bioscience Center, School of \\ Pharmacy, University of Kansas, Lawrence, KS, USA \\ ${ }^{b}$ College of Life Sciences, Beijing Normal University, Beijing, China \\ 'Department of Neurology, Memorial Sloan-Kettering Cancer Center, New York, NY, USA
}

\begin{abstract}
Diabetes is considered to be a risk factor in Alzheimer's disease (AD) pathogenesis. Although recent evidence indicates that diabetes exaggerates pathologic features of $\mathrm{AD}$, the underlying mechanisms are not well understood. To determine whether mitochondrial perturbation is associated with the contribution of diabetes to $\mathrm{AD}$ progression, we characterized mouse models of streptozotocin (STZ)-induced type 1 diabetes and transgenic AD mouse models with diabetes. Brains from mice with STZ-induced diabetes revealed a significant increase of cyclophilin D (CypD) expression, reduced respiratory function, and decreased hippocampal long-term potentiation (LTP); these animals had impaired spatial learning and memory. Hyperglycemia exacerbated the upregulation of CypD, mitochondrial defects, synaptic injury, and cognitive dysfunction in the brains of transgenic AD mice overexpressing amyloid- $\beta$ as shown by decreased mitochondrial respiratory complex I and IV enzyme activity and greatly decreased mitochondrial respiratory rate. Concomitantly, hippocampal LTP reduction and spatial learning and memory decline, two early pathologic indicators of $\mathrm{AD}$, were enhanced in the brains of diabetic AD mice. Our results suggest that the synergistic interaction between effects of diabetes and AD on mitochondria may be responsible for brain dysfunction that is in common in both diabetes and
\end{abstract} AD.

\section{Keywords}

Alzheimer's disease; cognitive impairment; diabetes; long-term potentiation; mitochondria; synaptic injury

\footnotetext{
(C) 2015 - IOS Press and the authors. All rights reserved

*Correspondence to: Dr. Shirley ShiDu Yan, Departments of Pharmacology and Toxicology and Higuchi Bioscience Center, School of Pharmacy, University of Kansas, 2099 Constant Avenue, Lawrence, KS 66047, USA. Tel.: +1 785864 3637; shidu@ ku.edu.

Authors' disclosures available online (http://www.j-alz.com/disclosures/view.php?id=2389).
} 


\section{INTRODUCTION}

Alzheimer's disease (AD) is an age-dependent neurodegenerative disorder functionally characterized by progressive cognitive decline. The primary pathological alterations in $\mathrm{AD}$ in brain parenchyma are progressive accumulation of amyloid- $\beta$ peptide $(A \beta)$ derived from amyloid- $\beta$ protein precursor (A $\beta \mathrm{PP})$ and neurofibrillary tangles derived from abnormal phosphorylation of tau protein $[1,2] . A \beta$ is formed after sequential cleavage of $A \beta P P$ and its most abundant isoforms are $A \beta_{40}$ and $A \beta_{42}$. Initially, $A \beta$ products are non-fibrillary and soluble, which can directly affect many intracellular components to induce neuronal malfunction. Among intracellular targets of $A \beta$, mitochondria play a central role in $A \beta$ mediated toxicity in synaptic injury, cognitive decline, and neuronal loss [3-15]. Accumulation of $\mathrm{A} \beta$ in $\mathrm{AD}$ patient brain and several transgenic mouse models of $\mathrm{AD}$ that overexpress $\mathrm{A} \beta$ progressively induce the increase of cyclophilin $\mathrm{D}(\mathrm{CypD})$, a critical component of mitochondrial permeable transition pore (mPTP), mitochondrial respiratory chain impairment, and energy failure. Interaction of $A \beta$ with mitochondrial proteins, such as amyloid-binding alcohol dehydrogenase (ABAD) [4, 15-18] and CypD [11,19, 20], exacerbates $A \beta$-induced mitochondrial respiratory complex enzyme defects, synaptic plasticity impairment, and learning and memory decline. Thus, CypD and its associated mitochondrial function play a critical role in AD progression.

Both $\mathrm{AD}$ and diabetes are prevalent in elderly patients. Diabetes is a disorder of glucose metabolism characterized by perturbation of the insulin-signaling pathway, which results in hyperglycemia. These disturbances result from hypoinsulinemia diabetes due to impaired production of insulin in the case of type 1 diabetes, or from insulin resistance in type 2 diabetes. Diabetes is a chronic disease with multiple severe complications and affects an estimated 25.8 million patients in the United States, according to the report in 2011 National Diabetes Fact sheet of the United States Centers for Disease Control and Prevention. In addition to the well-known adverse effects of diabetes on the cardiovascular and peripheral nervous systems, diabetes can also causes complications in the central nervous system (CNS) leading to ischemic stroke, episodic memory impairment [21], and synaptic plasticity deficit [22-30]. Synaptic dysfunction and learning and memory deficit, common to AD, have been observed in diabetic patients; in addition, many other features of $\mathrm{AD}$ pathology are identified in diabetic subjects. For example, elevated oxidative stress and impaired mitochondrial respiratory enzyme activity is often seen in diabetes in a variety of cell types including islet cells [31], hepatocytes [32], skeletal muscle cells [33, 34], blood mononuclear cells [35], endothelial cells [36], and dorsal root ganglion neurons [37, 38]. Mitochondrial dysfunction is also suggested to be a causative factor in the development of insulin resistance in skeletal muscle cells and hyperglycemia in type 2 diabetes [39, 40]. Compared to other cells, neurons are morphologically quite complicated and more susceptible to mitochondrial dysfunction because the neuronal transmission is tightly regulated by energy homeostasis in synapses. Mitochondrial alterations in hypothalamus have recently been identified as a control mechanism for food intake and energy expenditure, which in turn causes diet-induced obesity and diabetes [41]. Regardless whether mitochondrial dysfunction is a cause or a consequence of diabetes, we believe mitochondria play a critical role in diabetes-induced brain dysfunction. 
Recent epidemiological studies support a link between diabetes and AD in elderly patients [42]. A number of studies associate diabetes mellitus with AD pathogenesis [43-46]; indeed, it is considered a potential risk factor for developing AD [47]. Diabetes exacerbates features of AD pathology and learning and memory deficits in experimentally induced diabetes in mouse models of AD [46, 48-50]. However, the mechanisms underlying diabetes-induced synaptic dysfunction are not clear.

Mitochondrial dysfunction is critical to the development and progression of AD [3-15]. As the mitochondria are particularly affected by hyperglycemia in diabetes [31-38] and mitochondria play a key role in supporting synaptic plasticity, one of the mechanisms of learning and memory, [51, 52], we induced type 1 diabetes in transgenic AD mice overexpressing human $\mathrm{A} \beta$ ( $\mathrm{mA} \beta \mathrm{PP}$ mice) to determine whether mitochondrial perturbation is associated with the contribution of diabetes to $\mathrm{AD}$ progression.

\section{MATERIALS AND METHODS}

Animals

All studies were performed using the well-characterized transgenic $\mathrm{mA} \beta \mathrm{PP}$ mouse model, which overexpresses hA $\beta \mathrm{PP}$ that encodes the hA $\beta \mathrm{PP} 751-$, and hA $\beta \mathrm{PP} 770$-bearing mutations of human AD (V717F, K670N, and M671L) and the control wild-type (WT) mice. Transgenic lines were maintained by crossing $\mathrm{mA} \beta \mathrm{PP}$ transgenic mice with non-transgenic wild type (WT) C57BL/6 breeders. Animals were housed up to five per cage with free access to food and water and maintained in a vivarium proved by the American Association for the Accreditation of Laboratory Animal Care. All animal studies were approved by the Animal Care and Use Committee of the University of Kansas in accordance with the National Institutes of Health guidelines for animal care. Five to ten male mice were used per group.

\section{Induction of type 1 diabetes}

After being fasted for five hours, insulin-deficient diabetes was induced in 3 month-old mice by intraperitoneal (i.p.) injection of streptozotocin (STZ, Sigma, St. Louis, MO; dose 60 $\mathrm{mg} / \mathrm{kg}$ dissolved in $100 \mathrm{mM}$ citric acid, $\mathrm{pH} 4.5$ ) on 5 consecutive days. Hyperglycemia was confirmed using a strip-operated reflectance meter on a blood sample from tail prick 2 weeks after STZ injection and in another sample collected after the study (2 to 3 months after STZ injection). Citric acid ( $\mathrm{pH} 4.5$ ) was injected as a vehicle control. $0.9 \%$ saline solution was administered subcutaneously to maintain animal health.

\section{Morris water maze task}

Two months following STZ treatment, mice were trained in the Morris water maze. The maze is a circular pool of water, maintained at $24 \pm 1^{\circ} \mathrm{C}$, and divided into imaginary 4 quadrants. During daily training, an opaque (from white non-toxic paint) platform was placed in one of the quadrants and hidden $1 \mathrm{~cm}$ below the surface of water. Mice were trained to locate the hidden platform during four trials per day over 8 days. Starting points were changed every day. For each trial, mouse was allowed to search the platform for $60 \mathrm{~s}$. Mice failed to find the platform within $60 \mathrm{~s}$ will be guided to the platform and rest for $15 \mathrm{~s}$ 
before next trial. The time required for locating the submerged platform is termed "latency". Twenty-four hours after the last training session on day 8, each animal was given a single 60 s probe trial. The submerged platform was removed and the animal was expected to enter the target quadrant and make more entries into the location that previously contained the platform (memory retention). Time spent in the target quadrant, swim speed, and the number of entries into the platform location were recorded by video tracking.

\section{Electrophysiological studies}

Electrophysiological recordings were performed on coronal hippocampal slices ( $400 \mu \mathrm{m}$ in thickness), as described [11]. Briefly, the hippocampal slices were recovered at $37^{\circ} \mathrm{C}$ for at least $1 \mathrm{~h}$ and then maintained in an interface chamber at $29^{\circ} \mathrm{C}$ and perfused with artificial cerebrospinal fluid (124 mM NaCL, $4.4 \mathrm{mM} \mathrm{KCL}, 1 \mathrm{mM} \mathrm{Na} 2 \mathrm{HPO}_{4}, 25 \mathrm{mM} \mathrm{NaHCO}_{3}, 2$ $\mathrm{mM} \mathrm{CaCl}_{2}, 2.0 \mathrm{mM} \mathrm{MgSO}$, and $10 \mathrm{mM}$ glucose) continuously bubbled with $95 \% \mathrm{O}_{2}$ and $5 \% \mathrm{CO}_{2}$. Field-excitatory post-synaptic potentials (fEPSPs) were recorded for the CA1 hippocampal region by placing both the stimulating and the recording electrodes in the CA1 stratum radiatum. Basal synaptic transmission (input-output curve) was assayed by plotting the stimulus voltage $(\mathrm{V})$ against the slopes of fEPSPs to generate input-output relations. A $30 \mathrm{~min}$ baseline recording was established using low-frequency stimulation $(0.033 \mathrm{~Hz} ; 0.1$ ms impulse duration) and the adjusted intensity that induced fEPSPs with $\sim 30 \%$ of the maximal fEPSP amplitude. The LTP was induced using theta-burst stimulation (4 pulses at $100 \mathrm{~Hz}$, with bursts repeated at $5 \mathrm{~Hz}$, and each tetanus, including 3 10-burst trains separated by $15 \mathrm{~s}$. Values of the fEPSP slope were expressed as mean \pm SEM percentage change relative to their mean baseline amplitude.

\section{Immunoblotting analysis}

We have performed western blot to determine CypD content in hippocampus homogenates. The hippocampi were lysed in cell lysis buffer (Cell signaling \#9803; $20 \mathrm{mM}$ Tris-HCl (pH 7.5), $150 \mathrm{mM} \mathrm{NaCl}, 1 \mathrm{mM}$ EDTA, $1 \mathrm{mM}$ EGTA, $1 \%$ Triton, $2.5 \mathrm{mM}$ sodium pyrophosphate) containing protease inhibitor cocktail (Calbiochem, set V, EDTA free). Equal amount of proteins were loaded and separated by SDS-PAGE (12\% Bis-Tris gel, Invitrogen), and then transferred to nitrocellulose membrane (Amersham). Membrane was blocked in TBST buffer (20 mM Tris-HCl, $150 \mathrm{mM} \mathrm{NaCl}, 0.1 \%$ Tween-20) containing 5\% non-fat dry milk (SantaCruz) for $1 \mathrm{~h}$ at room temperature, and then incubated and gently shaken overnight $\left(\right.$ at $\left.4{ }^{\circ} \mathrm{C}\right)$ with anti-CypD $\operatorname{IgG}(1: 2000$, generated in our laboratory) in TBST containing $5 \%$ non-fat dry milk; this was followed by incubation with corresponding secondary antibody for $1 \mathrm{~h}$ at room temperature. Chemiluminescence was detected by using ECL (GE). The same membrane was stripped and reprobed with antibody to tubulin $(1: 10,000$, Sigma) as the protein loading control.

\section{Mitochondrial isolation}

Cortical mitochondria were isolated from whole brain cortex of mice as described previously [21]. Samples were placed in $9 \mathrm{ml}$ of ice-cold mitochondria isolation buffer [225 $\mathrm{mM}$ mannitol, $75 \mathrm{mM}$ sucrose, $2 \mathrm{mM} \mathrm{K}^{2} \mathrm{HPO}_{4}$ (pH 7.2)], and homogenized (10 strokes) using a Douce homogenizer (Kontes Glass Co.). Homogenate was centrifuged at $1300 \mathrm{~g}$ for 
$5 \mathrm{~min}$ at $4^{\circ} \mathrm{C}$. The resultant supernatant was then centrifuged at $34,000 \mathrm{~g}$ for $10 \mathrm{~min}$ after layering on $15 \%$ Percoll. After centrifugation, the homogenate was resuspended and incubated for $5 \mathrm{~min}$ on ice in $20 \mathrm{ml}$ of mitochondria isolation buffer with $0.02 \%$ digitonin, centrifuged at $8,000 \mathrm{~g}$ for $10 \mathrm{~min}$. The pellet was washed twice in $1.5 \mathrm{ml}$ mitochondria isolation buffer and centrifuges again at $8,000 \mathrm{~g}$ for $10 \mathrm{~min}$. The final pellet were resuspended in 200ul mitochondria isolation buffer. Total protein concentration of isolated mitochondria fraction was determined by Bio-Rad DC protein assay (Bio-Rad Lab).

\section{Mitochondrial oxygen consumption assay}

Mitochondrial respiration rate was measured using a Clark oxygen electrode (Oxytherm, Hansatech) at with mitochondria kept at $30^{\circ} \mathrm{C}$ as previously described [21]. Three hundred $\mu \mathrm{g}$ mitochondria were added to $1 \mathrm{ml}$ potassium buffer. State 3 respiration was triggered by the addition of $150 \mu \mathrm{M}$ adenosine diphosphate (ADP) in the presence of $5 \mathrm{mM}$ glutamate and $5 \mathrm{mM}$ malate; state 4 respiration is defined as oxygen consumption after ADP has been consumed. The respiratory control ratio (RCR) of mitochondria is calculated as state $3 /$ state 4.

\section{Mitochondrial respiratory chain complex activity measurement}

Mitochondrial respiratory chain complex activity was measured using the isolated mitochondrial fraction as described before [21, 53, 54]. Briefly, NADH: ubiquinone oxidoreductase (COX I) enzyme activity was determined in $25 \mathrm{mM}$ potassium buffer containing $\mathrm{KCl}$, Tris- $\mathrm{HCl}$ and EDTA (pH 7.4). The change in absorbance was monitored at $340 \mathrm{~nm}$ wavelength every $20 \mathrm{sec}$ for 6 min using an Amersham Bio-sciences Ultrospect 3100 pro spectrophotometer. In the presence of mitochondria (50 $\mu$ g protein), $2 \mu \mathrm{g} / \mathrm{ml}$ antimycin, $5 \mathrm{mM}$ magnesium chloride, $2 \mathrm{mM}$ potassium cyanine and $65 \mu \mathrm{M}$ co-enzymes Q1 were added and the oxidation of NADH was recorded for $3 \mathrm{~min}$; then $2 \mu \mathrm{g} / \mathrm{ml}$ rotenone was added and absorbance was measured for another $3 \mathrm{~min}$. For measurement of cytochrome $\mathrm{c}$ oxidase (COX IV) enzyme activity, mitochondrial samples (50 $\mu$ g protein) were gently added to a cuvette containing $0.95 \mathrm{~mL}$ of $1 \times$ assay buffer $(10 \mathrm{mM}$ Tris- $\mathrm{HCl}$, and $120 \mathrm{mM}$ potassium chloride, $\mathrm{pH} 7.0$ ), and the reaction volume was brought to $1.05 \mathrm{~mL}$ with the addition of $1 \times$ enzyme dilution buffer $(10 \mathrm{mM}$ Tris-HCl, $\mathrm{pH}$ 7.0). The reaction was then initiated by addition of $50 \mu \mathrm{L}$ of ferrocy-tochrome substrate solution $(0.22 \mathrm{mM})$. The change in absorbance of cytochrome $\mathrm{c}$ at $550 \mathrm{~nm}$ was measured using a kinetic program with a 5 -s delay, 10-s interval and a total of 6 readings on an Amersham Biosciences Ultrospect 3100 pro spectrophotometer. Non-enzymatic background was measured in the sample without the isolated mitochondrial fraction.

\section{Data analysis}

Data are presented as mean \pm SEM. Statistics analyses were performed using Statview software (SAS Institute). One-way ANOVA was followed by individual post hoc Fisher tests for statistical comparison. $p \leq 0.05$ was considered statistically significant. 


\section{RESULTS}

\section{Experimental induction of type 1 diabetes in $\mathrm{mA} \beta P P$ and nonTg mice}

Mice, which were injected with STZ (60 mg/kg i.p.) after five hours of fasting for five successive days, exhibited hyperglycemia (blood sugar $>250 \mathrm{mg} / \mathrm{dl}$ ) 2 weeks after initiation of STZ injection $(339.07 \pm 50.9 \mathrm{mg} / \mathrm{dl}$ in nonTg/STZ mice and $342.88 \pm 36.2 \mathrm{mg} / \mathrm{dl}$ in $\mathrm{mA} \beta \mathrm{PP} / \mathrm{STZ}$ mice, Fig. 1A). Two months later, blood glucose levels for diabetic mice remained significantly high in both $\mathrm{mA} \beta \mathrm{PP}(498.09 \pm 33.5 \mathrm{mg} / \mathrm{dl})$ and nonTg $(517.09 \pm 27.6$ $\mathrm{mg} / \mathrm{dl}$ ) mice (Fig. 1A). All mice maintained a healthy weight over the 2-month period (Fig. 1B). Mice injected with vehicle gained a small amount of weight over the 2-month period. Mice with induced diabetes lost weight, but the body weight loss was not significantly different between mA $\mathrm{PP}(-6.30 \pm 1.4 \mathrm{~g})$ and nonTg $(-5.79 \pm 1.0 \mathrm{~g})$ diabetic animals $(p>$ 0.05 , Fig. 1B). These results confirm that both nonTg and $\mathrm{mA} \beta \mathrm{PP}$ mice developed type 1 diabetes with hyperglycemia as early as 2 weeks after STZ treatment and the resultant hyperglycemia was sustained more than 2 months post STZ injection.

\section{Expression of CypD in diabetic and non-diabetic nonTg and $\mathrm{mA} \beta P P$ mice}

CypD is a necessary component of mPTP formation, triggering the opening of mPTP by translocation of CypD to the inner membrane of mitochondria and causes oxidative stress. Previously, we observed up-regulation of CypD in $\mathrm{mA} \beta \mathrm{PP}$ mice as compared to nonTg mice at the age of 6-12 months [11]. It is also demonstrated that CypD-mediated mPTP opening in face to high-fat diet treatment causes mitochondrial dysfunction and insulin resistance in skeletal muscle [55]. Therefore, it is possible that diabetes exaggerates CypD upregulation in the $\mathrm{mA} \beta \mathrm{PP}$ mouse brain. In the present study, we compared CypD levels in $\mathrm{mA} \beta \mathrm{PP}$ mice to nonTg mice when made diabetic. According to immunoblotting analysis, CypD levels in non-diabetic $\mathrm{mA} \beta \mathrm{PP}$ or diabetic nonTg hippocampus were significantly increased as compared to non-diabetic nonTg controls (Fig. 2, $p<0.05$ ). When mA $\beta$ PP mice rendered to STZ-induced type 1 diabetes, the CypD expression was further increased significantly (Fig. $2, p<0.05$ versus $\mathrm{mA} \beta \mathrm{PP} /$ Vehicle or nonTg/STZ mice).

\section{Increased brain mitochondrial dysfunction in diabetic mA $\beta P P$ mice}

Since mitochondria are vulnerable to changes in glucose homeostasis in diabetes and play a critical role in $\mathrm{AD}$ progression, we investigated whether experimentally induced type 1 diabetes exacerbated mitochondrial dysfunction in relatively young transgenic $\mathrm{AD}$ mice (before onset of clinically observable symptoms) with otherwise normal mitochondrial function. Mitochondrial respiration is critical for energy metabolism, cell functioning and survival. Decreased mitochondrial respiratory function indicates severe damage to mitochondria. We first analyzed mitochondrial respiration by measuring ADP-stimulated RCR. During the consumption of $150 \mu \mathrm{M}$ ADP, STZ-treated nonTg mice (nonTg/STZ) cortical mitochondria showed decreased RCR as compared to that found in vehicle-treated nonTg (nonTg/Vehicle mitochondria (Fig. 3A). With vehicle treatment, mAßPP cortical mitochondria showed compromised RCR $(4.92 \pm 0.1$ in $\mathrm{mA} \beta \mathrm{PP} /$ Vehicle mice, $p<0.05$ versus nonTg/Vehicle, Fig. 3A) compared to nonTg/Vehicle mitochondria. While the RCR was not significantly different between nonTg/STZ and $\mathrm{mA} \beta \mathrm{PP} /$ Vehicle mitochondria $(p>0.5)$, 
STZ-induced diabetic $\mathrm{mA} \beta \mathrm{PP}$ mice had a significant reduction in RCR compared to vehicletreated $\mathrm{mA} \beta \mathrm{PP}$ mice $(p<0.05$, Fig. 3A).

Cytochrome c oxidase (COX IV) activity was not significantly different when comparing nonTg/Vehicle, nonTg/STZ and $\mathrm{mA \beta PP} /$ Vehicle mice $(82.60 \pm 2.9 \mathrm{nmol} / \mathrm{mg}$ protein $/ \mathrm{min}$ in nonTg/Vehicle, $78.00 \pm 4.7 \mathrm{nmol} / \mathrm{mg}$ protein $/ \mathrm{min}$ in nonTg/STZ, $81.17 \pm 3.5 \mathrm{nmol} / \mathrm{mg}$ protein/min in $\mathrm{mA} \beta \mathrm{PP} /$ Vehicle mice, respectively, $p>0.05$, Fig. 3B). However, $\mathrm{mA} \beta \mathrm{PP} / \mathrm{STZ}$ mitochondria showed a significantly decreased COX IV activity compared to non-diabetic $\mathrm{mA} \beta \mathrm{PP}$ mitochondria $(64.20 \pm 8.0 \mathrm{nmol} / \mathrm{mg}$ protein $/ \mathrm{min}$ in $\mathrm{mA} \beta \mathrm{PP} / \mathrm{STZ}$ mice, $p<0.05$, Fig. 3B). Compared to vehicle-treated nonTg mice $(202.32 \pm 21.5 \mathrm{nmol} / \mathrm{mg}$ protein/min), COX I (NADH: ubiquinone oxidoreductase) activity was not significantly altered in nonTg/STZ $(201.38 \pm 31.1 \mathrm{nmol} / \mathrm{mg}$ protein $/ \mathrm{min})$ or $\mathrm{mA} \beta \mathrm{PP} /$ Vehicle $(197.42 \pm 26.9 \mathrm{nmol} / \mathrm{mg}$ protein/ min) mice ( $p>0.05$, Fig. $3 \mathrm{C})$. In contrast, STZ-mA $\beta$ PP mice had markedly decreased COX I activity (by $50-60 \%$ ) compared to non-diabetic mA $\beta$ PP mitochondria ( $p<0.01$, Fig. $3 \mathrm{C}$ ).

Taken together, these data indicated that the mitochondrial respiration was impaired in STZinduced diabetic nonTg mice (Fig. 3A) while COX I and COX IV activity remained unchanged (Fig. 3B-C). As reported previously [21], mAßPP mice at six to seven months of age had reduced RCR (Fig. 3A) but no detectable alterations in COX I or COX IV (Fig. 3BC). Intriguingly, the young $\mathrm{mA} \beta \mathrm{PP}$ mice with experimentally induced type 1 diabetes (STZ injection starting at three to four months of age) of two to three months duration showed early deficits in mitochondrial respiration and decline in both COX I and COX IV activity (Fig. 3).

\section{Early deficit in synaptic plasticity in diabetic mA}

Given that mitochondria are vital for maintenance of synaptic function and transmission, we examined synaptic transmission under basal conditions, paired-pulse facilitation (PPF, a form of short-term synaptic plasticity), and during long-term potentiation (LTP, a form of synaptic plasticity that is widely studied as a cellular model for learning and memory). Consistent with previous observations [23, 29, 30], fEPSPs in the CA1 stratum radiatum revealed no alterations in basal synaptic transmission (BST) and PPF in nondiabetic and diabetic nonTg mice ( $p>0.05$ nonTg/Vehicle versus nonTg/STZ, Fig. 4A-B). Compared to vehicle-treated nonTg mice, $\mathrm{mA} \beta \mathrm{PP} /$ Vehicle mice showed no significant difference in BST and PPF at 6-7 months of age ( $p>0.05 \mathrm{~mA} \beta \mathrm{PP} /$ Vehicle versus nonTg/Vehicle, Fig. 4A-B) until 10-12 month of age $[11,16,56]$. CA1 region hippocampal LTP was significantly decreased in diabetic nonTg mice $(143.07 \pm 5.1 \%)$ compared to non-diabetic nonTg mice $(209.41 \pm 12.5 \%, p<0.01$, Fig. 4C-D). However, diabetic mAßPP mice had significantly reduced hippocampal LTP compared to non-diabetic $\mathrm{mA} \beta \mathrm{PP}$ mice $(112.22 \pm 5.9 \%, p<0.01$ versus $\mathrm{mA} \beta \mathrm{PP} /$ Vehicle and $p<0.05$ versus nonTg/STZ, respectively, Fig. $4 \mathrm{C}-\mathrm{D})$. Young $(6$ to 7 months of age) vehicle-treated $\mathrm{mA} \beta \mathrm{PP}$ mice had normal LTP $(196.20 \pm 12.9 \%)$ $(p>0.05, \mathrm{~mA} \beta \mathrm{PP} /$ Vehicle versus nonTg/Vehicle, Fig. 4C-D). Young diabetic mA $\beta \mathrm{PP}$ mice had no changes in BST or PPF ( $p>0.05 \mathrm{~mA} \beta \mathrm{PP} /$ Vehicle versus mA $\beta P P / S T Z$, Fig. 4A, B). These data demonstrate an early deficit in synaptic dysfunction in diabetic $\mathrm{mA} \beta \mathrm{PP}$ mice, suggesting that type 1 diabetes worsens synaptic damage in the early stage AD brain, 
possibly due to deleterious effects of diabetes on mitochondrial respiratory function and enzyme activity.

\section{Learning and memory impairments were further aggravated in diabetic mA $\beta P P$ mice}

Behavioral change is a functional manifestation of mitochondrial dysfunction and synaptic injury. Previous studies showed that hippocampus is particularly susceptible to diabetesinduced spatial learning and memory impairment $[23,29]$ due to synaptic plasticity deficit. Similarly, hippocampus-dependent cognitive deficits have been reported in transgenic mAßPP mice, which from the age of six months to 22-24 months [11]. We next assessed the synergistic effects of type 1 diabetes on learning and memory in young $\mathrm{mA} \beta \mathrm{PP}$ mice. We evaluated spatial learning and memory in mice at age of six to seven months using a Morris water maze as previously described $[11,20]$. Vehicle-treated nonTg mice showed good learning and memory during the training session (Fig. 5A). $\mathrm{mA} \beta \mathrm{PP}$ mice treated with vehicle or STZ-treated nonTg mice required a longer time (higher latency) to locate the hidden platform during trials (Fig. 5A), indicating impaired spatial learning and memory. Notably, STZ-treated mAßPP mice had the longest latency to find the hidden platform (Fig. $5 \mathrm{~A})$.

In the memory retention test, both nonTg/STZ mice $(33.16 \pm 2.6 \%$ time in the target quadrant, and 2-3 crosses to the platform location) and $\mathrm{mA} \beta \mathrm{PP} /$ Vehicle mice $(23.80 \pm 1.9 \%$ time in the target quadrant, and 1-2 crosses to the platform location) displayed memory deficit compared to nonTg/Vehicle mice $(45.56 \pm 1.2 \%$ time in the target quadrant, and 4-5 crosses to the platform location) ( $p<0.01$, Fig. 5B, C). Similarly, memory retention was further impaired $(11.88 \pm 3.3 \%$ time in the target quadrant, and $0-1$ crosses to the platform location) in diabetic $\mathrm{mA} \beta \mathrm{PP}$ mice ( $p<0.01 \mathrm{~mA} \beta \mathrm{PP} /$ Vehicle versus $\mathrm{mA} \beta \mathrm{PP} / \mathrm{STZ}$, Fig. $5 \mathrm{~B}, \mathrm{C}$ ). We did not find any significant difference in swimming speed in the four groups of mice (Fig. 5D). These data demonstrate that diabetes accelerates cognitive dysfunction in $\mathrm{AD}$ mice.

\section{DISCUSSION}

There is growing evidence of links between AD and diabetes [43-46]. Aged patients with diabetes are at increased risk for $\mathrm{AD}$ [47]. While experimental induction of diabetes in mouse models of $A D$ exacerbates features of $A D$, including increased $A \beta$ formation and accumulation [46, 48-50], tau phosphorylation [46, 48, 50], and learning and memory deficit [46, 48-50], the underlying mechanisms are unclear. Mitochondria are particularly affected by hyperglycemia in diabetes [31-38] and mitochondrial and synaptic dysfunction is an early pathological feature of $\mathrm{AD}$-affected brain, playing a critical role in $\mathrm{AD}$ progression [3-15]. Therefore, the two diseases might share a common mitochondria-related mechanism that leads to brain dysfunction. In the present study, we induced type 1 diabetes in $\mathrm{mA} \beta \mathrm{PP}$ transgenic mice to test whether mitochondrial perturbation secondary to diabetes contributes to $\mathrm{AD}$ progression. Indeed, experimental induction of type 1 diabetes accelerated mitochondrial defects and exacerbated impairments in synaptic plasticity and spatial learning and memory in $\mathrm{mA} \beta \mathrm{PP}$ mice at 6-7 month old age. 
CypD is a key component of mPTP Oxidative and other cellular stresses promote CypD translocation to the inner membrane [57-62], which in turn triggers opening the mPTP leading to cell death. Low expression of CypD in brain mitochondria increases resistance of mPTP induced by calcium [63], whereas high levels of CypD in neuronal mitochondria result in their greater vulnerability to the opening of MPTP and require higher levels of cyclosporin A (an inhibitor of CypD) to inhibit mPTP opening [64]. Consistent with these observations, genetic deficiency in CypD protects cells against $\mathrm{Ca}^{2+}{ }_{-}$, oxidative stress-, or $\mathrm{A} \beta$-induced cell death [61, 65-67]. CypD has been reported to play a vital role in both ADinduced brain dysfunction $[11,20,68]$ and diabetes-induced peripheral organs damages such as heart [69, 70] and skeletal muscle [55]. In our present study, we found that CypD expression levels were significantly elevated in hippocampus of STZ-induced diabetic nonTg mice as compared to vehicle-nonTg mice (Fig. 2, $p<0.05$ ). When mA $\beta P$ mice were subjected to STZ-induced type 1 diabetes, the CypD expression was further increased significantly in hippocampus of diabetic $\mathrm{mA} \beta \mathrm{PP}$ mice as compared with non-diabetic $\mathrm{mA} \beta \mathrm{PP}$ mice (Fig. $2, p<0.05$ versus $\mathrm{mA} \beta \mathrm{PP} /$ Vehicle or nonTg/STZ mice). These data suggested that CypD expression level was increased in diabetes mellitus and further enhanced in an $\mathrm{A} \beta$-enriched environment. Increased amount of CypD in mitochondria would trigger/enhance the opening of $\mathrm{mPTP}$, which leads to colloid osmotic swelling of the mitochondrial matrix, dissipation of the inner membrane potential $\left(\Delta \Psi_{\mathrm{m}}\right)$, accumulation/ generation of reactive oxygen species, and the release of many pro-apoptogenic proteins and procaspases [71-75]. Indeed, our previous studies demonstrated an upregulation of $\mathrm{CypD}$ in non-diabetic $\mathrm{mA} \beta \mathrm{PP}$ mice as compared to nonTg mice at the age of 6-12 months [11]. CypD-deficiency in $\mathrm{AD}$ mice overexpressing human $\mathrm{A} \beta$ protected from $\mathrm{A} \beta$-induced mitochondrial oxidative stress, increased capacity of mitochondrial calcium uptake, improved synaptic function, and ameliorated cognitive deficits [11, 20]. Additionally, CypD-mediated mPTP opening in face to high-fat diet treatment causes mitochondrial dysfunction and insulin resistance in skeletal muscle [55]. Therefore, CypD-mediated mPTP opening may be one of the mechanisms for diabetes-accelerated mitochondrial dysfunction in AD brain, which could ultimately contribute to synaptic injury and cognitive deficits in diabetic AD mice. Other mPTP components such as the voltage dependent anion channel [76] in the outer membrane and the adenine nucleotide translocase in the inner membrane may also contribute importantly to mitochondrial dysfunction in diabetes mellitus. The detailed mechanistic studies relevant to $\mathrm{mPTP}$ in diabetes are required for the further investigation.

Mitochondrial dysfunction is known to play an important mechanistic role in both diabetes and AD. Mitochondrial respiration is the most important function of mitochondria and healthy respiratory function is required for normal mitochondrial function. While no significant alterations were observed in COX I or COX IV activity, decreased mitochondrial RCR in cortical mitochondria of diabetic nonTg and non-diabetic mA $\beta P P$ littermates suggest impaired mitochondrial function. Early mitochondrial respiratory rate decline and impaired COX I and COX IV activity in cortical mitochondria from STZ-induced diabetic mAßPP mice suggest that type 1 diabetes exaggerates mitochondrial dysfunction at the early stage $\mathrm{AD}$. Because respiratory chain reflects electron flux through complexes I, III, and IV, inactivation of enzyme activities associated with anyone/or all of these complexes in the 
respiratory chain could disturb the respiratory chain function, leading to decreased oxygen consumption. Thus, reduced complex I and IV activity could be the mechanism for perturbing mitochondrial respiratory chain function observed in diabetic $\mathrm{mA} \beta \mathrm{PP}$ mice.

Mitochondria are essential for synaptic function by providing energy and regulating intrasynaptic metabolic homeostasis [51, 52]. Damaged mitochondria in diabetic mA $\beta P P$ mice are associated with synaptic injury. Consistent with previous reports [23, 29, 30], we observed LTP impairment in hippocampal CA1 region of STZ-treated animals. The LTP defect was significantly exacerbated in diabetic $\mathrm{mA} \beta \mathrm{PP}$ mice though there was no significant synaptic plasticity deficit in young (6-7 month of age) mA $\beta P$ littermates, suggesting an accelerated $\mathrm{AD}$ progression with diabetes insult.

Decreased mitochondrial and synaptic function in diabetic young $\mathrm{mA} \beta \mathrm{PP}$ mice is associated with a poor performance on the Morris water maze, reflecting impaired memory formation and retention. These differences in performance are not due to decreased swim speed, thereby excluding systemic consequences such as weight loss. We observed mildly impaired spatial learning and memory in diabetic nonTg mice compared to non-diabetic controls (Fig. 5). STZ-induced diabetic $\mathrm{mA} \beta \mathrm{PP}$ mice experienced significantly enhanced cognitive decline compared to non-diabetic mA $\beta \mathrm{PP}$ mice. Thus, diabetes may be an exacerbating factor, at least in part, for $\mathrm{AD}$-associated changes in learning and memory, especially in early stage $\mathrm{AD}$.

Another potential mechanism underlying diabetes-induced mitochondrial and synaptic dysfunction in $\mathrm{mA} \beta \mathrm{PP}$ mice may root in potentiated $\mathrm{A} \beta$ production, in parallel to the enhanced CypD expression. In our present study, $A \beta_{40}$ and $A \beta_{42}$ levels were significantly increased in $\mathrm{mA} \beta \mathrm{PP}$ mice with and without STZ treatment compared to STZ-treated nonTg mice. However, no significant differences of A $\beta$ levels were found between STZ-mA $\beta$ PP and vehicle-mA $\beta P P$ mice (data not shown). These results are consistent with previous studies showing no effect on $\mathrm{A} \beta$ production in either STZ-injected $\mathrm{mA} \beta \mathrm{PP} / \mathrm{PS} 1$ mice (A $\beta \mathrm{PP} /$ Ps1-STZ mice) [49] or leptin-deficient $\mathrm{mA} \beta \mathrm{PP}$ subjects ( $\mathrm{mA} \beta \mathrm{PP}-\mathrm{ob} / \mathrm{ob}$ mice) [77]. Using high-fat diet-induced aging mouse model, A $\beta$ levels were increased in brain of high-fat dietinduced senescence-accelerated SAMP8 mice (HF-SAMP8 mice) [50]. In addition, increasing evidence demonstrate that induction of chronic diabetes in transgenic mouse model of $\mathrm{AD}$ (in both HF-SAMP8 and mA $\beta$ PP-ob/ob mice) increases $\mathrm{A} \beta$ accumulation in brain microvascular vessels $[46,77]$. These studies suggest the close relationship of the chronic diabetes with A $\beta$ accumulation. Our recent preliminary results showed a significant increased cerebellar $\mathrm{A} \beta$ level in brain of type 2 diabetes mouse model (DB/DB mice, data not shown). Nevertheless, up-regulation of CypD expression in diabetic AD mouse brain could be a link of mitochondrial perturbation to synaptic and cognitive dysfunction in an early stage of $\mathrm{AD}$ progression.

In summary, we provide evidence that diabetes-mediated mitochondrial perturbation is linked to synaptic dysfunction as well as learning and memory deficit, contributing to the early stage AD progression. Hyperglycemia may accelerate the onset of neurochemical indices of CNS damage in AD pathogenesis. Our results clearly revealed that CypD was elevated in hippocampus when mice were rendered to experimental induction of type 1 
diabetes. Intriguingly, there is a synergistic exacerbation of hippocampal CypD upregulation in diabetes and diabetic AD mice. Such modulation of CypD expression may be one of the mechanisms for diabetes-accelerated mitochondrial dysfunction in AD brain, which could ultimately contribute to synaptic injury and cognitive deficits when superimposed with $A \beta$ toxicity. Thus, preserving mitochondrial function may be beneficial in halting hyperglycemia-associated AD progression. Although many differences exist, some features such as hyperglycemia are common in both type 1 and type 2 diabetes. Given that type 2 diabetes is more common in patients, it will be highly interest of understanding the role and regulation of brain mitochondria in CNS complications of type 2 diabetes as well.

\section{ACKNOWLEDGMENTS}

This work was supported by grants from the National Institute of Aging (R37AG037319). We are grateful of Jianping Li's assistant in measuring mitochondrial function.

\section{REFERENCES}

1. Querfurth HW, LaFerla FM. Alzheimer's disease. N Engl J Med. 2010; 362:329-344. [PubMed: 20107219]

2. Hardy J, Selkoe DJ. The amyloid hypothesis of Alzheimer's disease: Progress and problems on the road to therapeutics. Science. 2002; 297:353-356. [PubMed: 12130773]

3. Fernandez-Vizarra P, Fernandez AP, Castro-Blanco S, Serrano J, Bentura ML, Martinez-Murillo R, Martinez A, Rodrigo J. Intra- and extracellular Abeta and PHF in clinically evaluated cases of Alzheimer's disease. Histol Histopathol. 2004; 19:823-844. [PubMed: 15168346]

4. Lustbader JW, Cirilli M, Lin C, Xu HW, Takuma K, Wang N, Caspersen C, Chen X, Pollak S, Chaney M, Trinchese F, Liu S, Gunn-Moore F, Lue LF, Walker DG, Kuppusamy P, Zewier ZL, Arancio O, Stern D, Yan SS, Wu H. ABAD directly links Abeta to mitochondrial toxicity in Alzheimer's disease. Science. 2004; 304:448-452. [PubMed: 15087549]

5. Hirai K, Aliev G, Nunomura A, Fujioka H, Russell RL, Atwood CS, Johnson AB, Kress Y, Vinters HV, Tabaton M, Shimohama S, Cash AD, Siedlak SL, Harris PL, Jones PK, Petersen RB, Perry G, Smith MA. Mitochondrial abnormalities in Alzheimer's disease. J Neurosci. 2001; 21:3017-3023. [PubMed: 11312286]

6. Devi L, Prabhu BM, Galati DF, Avadhani NG, Anandatheerthavarada HK. Accumulation of amyloid precursor protein in the mitochondrial import channels of human Alzheimer's disease brain is associated with mitochondrial dysfunction. J Neurosci. 2006; 26:9057-9068. [PubMed: 16943564]

7. Crouch PJ, Blake R, Duce JA, Ciccotosto GD, Li QX, Barnham KJ, Curtain CC, Cherny RA, Cappai R, Dyrks T, Masters CL, Trounce IA. Copper-dependent inhibition of human cytochrome c oxidase by a dimeric conformer of amyloid-beta1-42. J Neurosci. 2005; 25:672-679. [PubMed: 15659604]

8. Caspersen C, Wang N, Yao J, Sosunov A, Chen X, Lustbader JW, Xu HW, Stern D, McKhann G, Yan SD. Mitochondrial Abeta: A potential focal point for neuronal metabolic dysfunction in Alzheimer's disease. FASEB J. 2005; 19:2040-2041. [PubMed: 16210396]

9. Manczak M, Anekonda TS, Henson E, Park BS, Quinn J, Reddy PH. Mitochondria are a direct site of A beta accumulation in Alzheimer's disease neurons: Implications for free radical generation and oxidative damage in disease progression. Hum Mol Genet. 2006; 15:1437-1449. [PubMed: 16551656]

10. Gillardon F, Rist W, Kussmaul L, Vogel J, Berg M, Danzer K, Kraut N, Hengerer B. Proteomic and functional alterations in brain mitochondria from $\mathrm{Tg} 2576$ mice occur before amyloid plaque deposition. Proteomics. 2007; 7:605-616. [PubMed: 17309106]

11. Du H, Guo L, Fang F, Chen D, Sosunov AA, McKhann GM, Yan Y, Wang C, Zhang H, Molkentin JD, Gunn-Moore FJ, Vonsattel JP, Arancio O, Chen JX, Yan SD. Cyclophilin D deficiency 
attenuates mitochondrial and neuronal perturbation and ameliorates learning and memory in Alzheimer's disease. Nat Med. 2008; 14:1097-1105. [PubMed: 18806802]

12. Hansson Petersen CA, Alikhani N, Behbahani H, Wiehager B, Pavlov PF, Alafuzoff I, Leinonen $\mathrm{V}$, Ito A, Winblad B, Glaser E, Ankarcrona M. The amyloid beta-peptide is imported into mitochondria via the TOM import machinery and localized to mitochondrial cristae. Proc Natl Acad Sci U S A. 2008; 105:13145-13150. [PubMed: 18757748]

13. Du H, Guo L, Yan SS. Synaptic mitochondrial pathology in Alzheimer's disease. Antioxid Redox Signal. 2012; 16:1467-1475. [PubMed: 21942330]

14. Abramowski D, Rabe S, Upadhaya AR, Reichwald J, Danner S, Staab D, Capetillo-Zarate E, Yamaguchi H, Saido TC, Wiederhold KH, Thal DR, Staufenbiel M. Trans-genic expression of intraneuronal Abeta42 but not Abeta40 leads to cellular Abeta lesions, degeneration, and functional impairment without typical Alzheimer's disease pathology. J Neurosci. 2012; 32:12731283. [PubMed: 22279212]

15. Yao J, Irwin RW, Zhao L, Nilsen J, Hamilton RT, Brinton RD. Mitochondrial bioenergetic deficit precedes Alzheimer's pathology in female mouse model of Alzheimer's disease. Proc Natl Acad Sci U S A. 2009; 106:14670-14675. [PubMed: 19667196]

16. Takuma K, Yao J, Huang J, Xu H, Chen X, Luddy J, Trillat AC, Stern DM, Arancio O, Yan SS. ABAD enhances Abeta-induced cell stress via mitochondrial dysfunction. FASEB J. 2005; 19:597-598. [PubMed: 15665036]

17. Yao J, Du H, Yan S, Fang F, Wang C, Lue LF, Guo L, Chen D, Stern DM, Gunn Moore FJ, Xi Chen J, Arancio O, Yan SS. Inhibition of amyloid-beta (Abeta) peptide-binding alcohol dehydrogenase-Abeta interaction reduces Abeta accumulation and improves mitochondrial function in a mouse model of Alzheimer's disease. J Neurosci. 2011; 31:2313-2320. [PubMed: 21307267]

18. Yan SD, Fu J, Soto C, Chen X, Zhu H, Al-Mohanna F, Collison K, Zhu A, Stern E, Saido T, Tohyama M, Ogawa S, Roher A, Stern D. An intracellular protein that binds amyloid-beta peptide and mediates neurotoxicity in Alzheimer's disease. Nature. 1997; 389:689-695. [PubMed: 9338779]

19. Du H, Yan SS. Mitochondrial permeability transition pore in Alzheimer's disease: Cyclophilin D and amyloid beta. Biochim Biophys Acta. 2010; 1802:198-204. [PubMed: 19616093]

20. Du H, Guo L, Zhang W, Rydzewska M, Yan S. Cyclophilin D deficiency improves mitochondrial function and learning/memory in aging Alzheimer disease mouse model. Neurobiol Aging. 2011; 32:398-406. [PubMed: 19362755]

21. Messier C. Impact of impaired glucose tolerance and type 2 diabetes on cognitive aging. Neurobiol Aging. 2005; 26(Suppl 1):26-30. [PubMed: 16236384]

22. Li XL, Aou S, Oomura Y, Hori N, Fukunaga K, Hori T. Impairment of long-term potentiation and spatial memory in leptin receptor-deficient rodents. Neuroscience. 2002; 113:607-615. [PubMed: 12150780]

23. Biessels GJ, Kamal A, Ramakers GM, Urban IJ, Spruijt BM, Erkelens DW, Gispen WH. Place learning and hippocampal synaptic plasticity in streptozotocin-induced diabetic rats. Diabetes. 1996; 45:1259-1266. [PubMed: 8772732]

24. Abbas T, Faivre E, Holscher C. Impairment of synaptic plasticity and memory formation in GLP-1 receptor KO mice: Interaction between type 2 diabetes and Alzheimer's disease. Behav Brain Res. 2009; 205:265-271. [PubMed: 19573562]

25. Artola A, Kamal A, Ramakers GM, Biessels GJ, Gispen WH. Diabetes mellitus concomitantly facilitates the induction of long-term depression and inhibits that of long-term potentiation in hippocampus. Eur J Neurosci. 2005; 22:169-178. [PubMed: 16029206]

26. Martin ED, Sanchez-Perez A, Trejo JL, Martin-Aldana JA, Cano Jaimez M, Pons S, Acosta Umanzor C, Menes L, White MF, Burks DJ. IRS-2 deficiency impairs NMDA receptor-dependent long-term potentiation. Cereb Cortex. 2012; 22:1717-1727. [PubMed: 21955917]

27. Nistico R, Cavallucci V, Piccinin S, Macri S, Pignatelli M, Mehdawy B, Blandini F, Laviola G, Lauro D, Mercuri NB, D'Amelio M. Insulin receptor beta-subunit haploinsufficiency impairs hippocampal late-phase LTP and recognition memory. Neuromolecular Med. 2012; 14:262-269. [PubMed: 22661254] 
28. Stranahan AM, Arumugam TV, Lee K, Mattson MP. Mineralocorticoid receptor activation restores medial perforant path LTP in diabetic rats. Synapse. 2010; 64:528-532. [PubMed: 20196138]

29. Stranahan AM, Arumugam TV, Cutler RG, Lee K, Egan JM, Mattson MP. Diabetes impairs hippocampal function through glucocorticoid-mediated effects on new and mature neurons. Nat Neurosci. 2008; 11:309-317. [PubMed: 18278039]

30. Shonesy BC, Thiruchelvam K, Parameshwaran K, Rahman EA, Karuppagounder SS, Huggins KW, Pinkert CA, Amin R, Dhanasekaran M, Suppiramaniam V. Central insulin resistance and synaptic dysfunction in intracerebroventricular-streptozotocin injected rodents. Neurobiol Aging. 2012; 33:430. e435-418. [PubMed: 21256630]

31. Molina AJ, Wikstrom JD, Stiles L, Las G, Mohamed H, Elorza A, Walzer G, Twig G, Katz S, Corkey BE, Shirihai OS. Mitochondrial networking protects beta-cells from nutrient-induced apoptosis. Diabetes. 2009; 58:2303-2315. [PubMed: 19581419]

32. Yu T, Robotham JL, Yoon Y. Increased production of reactive oxygen species in hyperglycemic conditions requires dynamic change of mitochondrial morphology. Proc Natl Acad Sci U S A. 2006; 103:2653-2658. [PubMed: 16477035]

33. Bach D, Pich S, Soriano FX, Vega N, Baumgartner B, Oriola J, Daugaard JR, Lloberas J, Camps M, Zierath JR, Rabasa-Lhoret R, Wallberg-Henriksson H, Laville M, Palacin M, Vidal H, Rivera F, Brand M, Zorzano A. Mitofusin-2 determines mitochondrial network architecture and mitochondrial metabolism. A novel regulatory mechanism altered in obesity. J Biol Chem. 2003; 278:17190-17197. [PubMed: 12598526]

34. Zorzano A, Liesa M, Palacin M. Role of mitochondrial dynamics proteins in the pathophysiology of obesity and type 2 diabetes. Int J Biochem Cell Biol. 2009; 41:1846-1854. [PubMed: 19703653]

35. Widlansky ME, Wang J, Shenouda SM, Hagen TM, Smith AR, Kizhakekuttu TJ, Kluge MA, Weihrauch D, Gutter-man DD, Vita JA. Altered mitochondrial membrane potential, mass, and morphology in the mononuclear cells of humans with type 2 diabetes. Transl Res. 2010; 156:1525. [PubMed: 20621033]

36. Makino A, Scott BT, Dillmann WH. Mitochondrial fragmentation and superoxide anion production in coronary endothelial cells from a mouse model of type 1 diabetes. Diabetologia. 2010; 53:17831794. [PubMed: 20461356]

37. Edwards JL, Quattrini A, Lentz SI, Figueroa-Romero C, Cerri F, Backus C, Hong Y, Feldman EL. Diabetes regulates mitochondrial biogenesis and fission in mouse neurons. Diabetologia. 2010; 53:160-169. [PubMed: 19847394]

38. Vincent AM, Edwards JL, McLean LL, Hong Y, Cerri F, Lopez I, Quattrini A, Feldman EL. Mitochondrial biogenesis and fission in axons in cell culture and animal models of diabetic neuropathy. Acta Neuropathol. 2010; 120:477-489. [PubMed: 20473509]

39. Lowell BB, Shulman GI. Mitochondrial dysfunction and type 2 diabetes. Science. 2005; 307:384387. [PubMed: 15662004]

40. Kelley DE, He J, Menshikova EV, Ritov VB. Dysfunction of mitochondria in human skeletal muscle in type 2 diabetes. Diabetes. 2002; 51:2944-2950. [PubMed: 12351431]

41. Schneeberger M, Dietrich MO, Sebastian D, Imbernon M, Castano C, Garcia A, Esteban Y, Gonzalez-Franquesa A, Rodriguez IC, Bortolozzi A, Garcia-Roves PM, Gomis R, Nogueiras R, Horvath TL, Zorzano A, Claret M. Mitofusin 2 in POMC neurons connects ER stress with leptin resistance and energy imbalance. Cell. 2013; 155:172-187. [PubMed: 24074867]

42. Maher PA, Schubert DR. Metabolic links between diabetes and Alzheimer's disease. Expert Rev Neurother. 2009; 9:617-630. [PubMed: 19402773]

43. Leibson CL, Rocca WA, Hanson VA, Cha R, Kokmen E, Obrien PC, Palumbo PJ. Risk of dementia among persons with diabetes mellitus: A population-based cohort study. Am J Epidemiol. 1997; 145:301-308. [PubMed: 9054233]

44. Ott A, Stolk RP, Hofman A, vanHarskamp F, Grobbee DE, Breteler MMB. Association of diabetes mellitus and dementia: The Rotterdam study. Diabetologia. 1996; 39:1392-1397. [PubMed: 8933010]

45. Xu WL, Qiu CX, Winblad B, Fratiglioni L. The effect of borderline diabetes on the risk of dementia and Alzheimer's disease. Diabetes. 2007; 56:211-216. [PubMed: 17192484] 
46. Currais A, Prior M, Lo D, Jolivalt C, Schubert D, Maher P. Diabetes exacerbates amyloid and neurovascular pathology in aging-accelerated mice. Aging Cell. 2012; 11:1017-1026. [PubMed: 22938075]

47. Akomolafe A, Beiser A, Meigs PB, Au R, Green RC, Farrer LA, Wolf PA, Seshadri S. Diabetes mellitus and risk of developing Alzheimer disease-Results from the Framingham study. Arch Neurol. 2006; 63:1551-1555. [PubMed: 17101823]

48. Jolivalt CG, Hurford R, Lee CA, Dumaop W, Rockenstein E, Masliah E. Type 1 diabetes exaggerates features of Alzheimer's disease in APP transgenic mice. Exp Neurol. 2010; 223:422431. [PubMed: 19931251]

49. Burdo JR, Chen Q, Calcutt NA, Schubert D. The pathological interaction between diabetes and presymptomatic Alzheimer's disease. Neurobiol Aging. 2009; 30:1910-1917. [PubMed: 18372080]

50. Mehla J, Chauhan BC, Chauhan NB. Experimental induction of type 2 diabetes in agingaccelerated mice triggered Alzheimer-like pathology and memory deficits. J Alzheimers Dis. 2014; 39:145-162. [PubMed: 24121970]

51. Kimura R, Ma LY, Wu C, Turner D, Shen JX, Ellsworth K, Wakui M, Maalouf M, Wu J. Acute exposure to the mitochondrial complex I toxin rotenone impairs synaptic long-term potentiation in rat hippocampal slices. CNS Neurosci Ther. 2012; 18:641-646. [PubMed: 22613619]

52. Levy M, Faas GC, Saggau P, Craigen WJ, Sweatt JD. Mitochondrial regulation of synaptic plasticity in the hippocampus. J Biol Chem. 2003; 278:17727-17734. [PubMed: 12604600]

53. Tieu K, Perier C, Caspersen C, Teismann P, Wu DC, Yan SD, Naini A, Vila M, Jackson-Lewis V, Ramasamy R, Przedborski S. D-beta-hydroxybutyrate rescues mitochondrial respiration and mitigates features of Parkinson disease. J Clin Invest. 2003; 112:892-901. [PubMed: 12975474]

54. Gan X, Huang S, Wu L, Wang Y, Hu G, Li G, Zhang H, Yu H, Swerdlow RH, Chen JX, Yan SS. Inhibition of ERK-DLP1 signaling and mitochondrial division alleviates mitochondrial dysfunction in Alzheimer's disease cybrid cell. Biochim Biophys Acta. 2013; 1842:220-231. [PubMed: 24252614]

55. Taddeo EP, Laker RC, Breen DS, Akhtar YN, Kenwood BM, Liao JA, Zhang M, Fazakerley DJ, Tomsig JL, Harris TE, Keller SR, Chow JD, Lynch KR, Chokki M, Molkentin JD, Turner N, James DE, Yan Z, Hoehn KL. Opening of the mitochondrial permeability transition pore links mitochondrial dysfunction to insulin resistance in skeletal muscle. Mol Metab. 2014; 3:124-134. [PubMed: 24634818]

56. Arancio O, Zhang HP, Chen X, Lin C, Trinchese F, Puzzo D, Liu S, Hegde A, Yan SF, Stern A, Luddy JS, Lue LF, Walker DG, Roher A, Buttini M, Mucke L, Li W, Schmidt AM, Kindy M, Hyslop PA, Stern DM, Du Yan SS. RAGE potentiates Abeta-induced perturbation of neuronal function in transgenic mice. EMBO J. 2004; 23:4096-4105. [PubMed: 15457210]

57. Crompton M, Virji S, Ward JM. Cyclophilin-D binds strongly to complexes of the voltagedependent anion channel and the adenine nucleotide translocase to form the permeability transition pore. Eur J Biochem. 1998; 258:729-735. [PubMed: 9874241]

58. Halestrap AP, Woodfield KY, Connern CP. Oxidative stress, thiol reagents, and membrane potential modulate the mitochondrial permeability transition by affecting nucleotide binding to the adenine nucleotide translocase. J Biol Chem. 1997; 272:3346-3354. [PubMed: 9013575]

59. Connern CP, Halestrap AP. Recruitment of mitochondrial cyclophilin to the mitochondrial inner membrane under conditions of oxidative stress that enhance the opening of a calcium-sensitive non-specific channel. Biochem J. 1994; 302(Pt 2):321-324. [PubMed: 7522435]

60. Andreeva L, Heads R, Green CJ. Cyclophilins and their possible role in the stress response. Int J Exp Pathol. 1999; 80:305-315. [PubMed: 10632780]

61. Baines CP, Kaiser RA, Purcell NH, Blair NS, Osinska H, Hambleton MA, Brunskill EW, Sayen MR, Gottlieb RA, Dorn GW, Robbins J, Molkentin JD. Loss of cyclophilin D reveals a critical role for mitochondrial permeability transition in cell death. Nature. 2005; 434:658-662. [PubMed: 15800627]

62. Pastorino JG, Chen ST, Tafani M, Snyder JW, Farber JL. The overexpression of Bax produces cell death upon induction of the mitochondrial permeability transition. J Biol Chem. 1998; 273:77707775. [PubMed: 9516487] 
63. Eliseev RA, Filippov G, Velos J, VanWinkle B, Goldman A, Rosier RN, Gunter TE. Role of cyclophilin D in the resistance of brain mitochondria to the permeability transition. Neurobiol Aging. 2007; 28:1532-1542. [PubMed: 16876914]

64. Hajnoczky G, Hoek JB. Cell signaling. Mitochondrial longevity pathways. Science. 2007; 315:607-609. [PubMed: 17272709]

65. Nakagawa T, Shimizu S, Watanabe T, Yamaguchi O, Otsu K, Yamagata H, Inohara H, Kubo T, Tsujimoto Y. Cyclophilin D-dependent mitochondrial permeability transition regulates some necrotic but not apoptotic cell death. Nature. 2005; 434:652-658. [PubMed: 15800626]

66. Basso E, Fante L, Fowlkes J, Petronilli V, Forte MA, Bernardi P. Properties of the permeability transition pore in mitochondria devoid of Cyclophilin D. J Biol Chem. 2005; 280:18558-18561. [PubMed: 15792954]

67. Schinzel AC, Takeuchi O, Huang Z, Fisher JK, Zhou Z, Rubens J, Hetz C, Danial NN, Moskowitz MA, Korsmeyer SJ. Cyclophilin D is a component of mitochondrial permeability transition and mediates neuronal cell death after focal cerebral ischemia. Proc Natl Acad Sci U S A. 2005; 102:12005-12010. [PubMed: 16103352]

68. Du H, Guo L, Yan S, Sosunov AA, McKhann GM, Yan SS. Early deficits in synaptic mitochondria in an Alzheimer's disease mouse model. Proc Natl Acad Sci U S A. 2010; 107:18670-18675. [PubMed: 20937894]

69. Itoh T, Kouzu H, Miki T, Tanno M, Kuno A, Sato T, Sunaga D, Murase H, Miura T. Cytoprotective regulation of the mitochondrial permeability transition pore is impaired in type 2 diabetic Goto-Kakizaki rat hearts. J Mol Cell Cardiol. 2012; 53:870-879. [PubMed: 23063677]

70. Lumini-Oliveira J, Magalhaes J, Pereira CV, Moreira AC, Oliveira PJ, Ascensao A. Endurance training reverts heart mitochondrial dysfunction, permeability transition and apoptotic signaling in long-term severe hyperglycemia. Mitochondrion. 2011; 11:54-63. [PubMed: 20654738]

71. Liu X, Kim CN, Yang J, Jemmerson R, Wang X. Induction of apoptotic program in cell-free extracts: Requirement for dATP and cytochrome c. Cell. 1996; 86:147-157. [PubMed: 8689682]

72. Zou H, Henzel WJ, Liu X, Lutschg A, Wang X. Apaf-1, a human protein homologous to C. elegans CED-4, participates in cytochrome c-dependent activation of caspase-3. Cell. 1997; 90:405-413. [PubMed: 9267021]

73. Susin SA, Lorenzo HK, Zamzami N, Marzo I, Brenner C, Larochette N, Prevost MC, Alzari PM, Kroemer G. Mitochondrial release of caspase- 2 and- 9 during the apoptotic process. J Exp Med. 1999; 189:381-394. [PubMed: 9892620]

74. Adrain C, Creagh EM, Martin SJ. Apoptosis-associated release of Smac/DIABLO from mitochondria requires active caspases and is blocked by Bcl-2. EMBO J. 2001; 20:6627-6636. [PubMed: 11726499]

75. Li LY, Luo X, Wang X. Endonuclease G is an apoptotic DNase when released from mitochondria. Nature. 2001; 412:95-99. [PubMed: 11452314]

76. Manczak M, Sheiko T, Craigen WJ, Reddy PH. Reduced VDAC1 protects against Alzheimer's disease, mitochondria, and synaptic deficiencies. J Alzheimers Dis. 2013; 37:679-690. [PubMed: 23948905]

77. Takeda S, Sato N, Uchio-Yamada K, Sawada K, Kunieda T, Takeuchi D, Kurinami H, Shinohara M, Rakugi H, Morishita R. Diabetes-accelerated memory dysfunction via cerebrovascular inflammation and Abeta deposition in an Alzheimer mouse model with diabetes. Proc Natl Acad Sci U S A. 2010; 107:7036-7041. [PubMed: 20231468] 
A

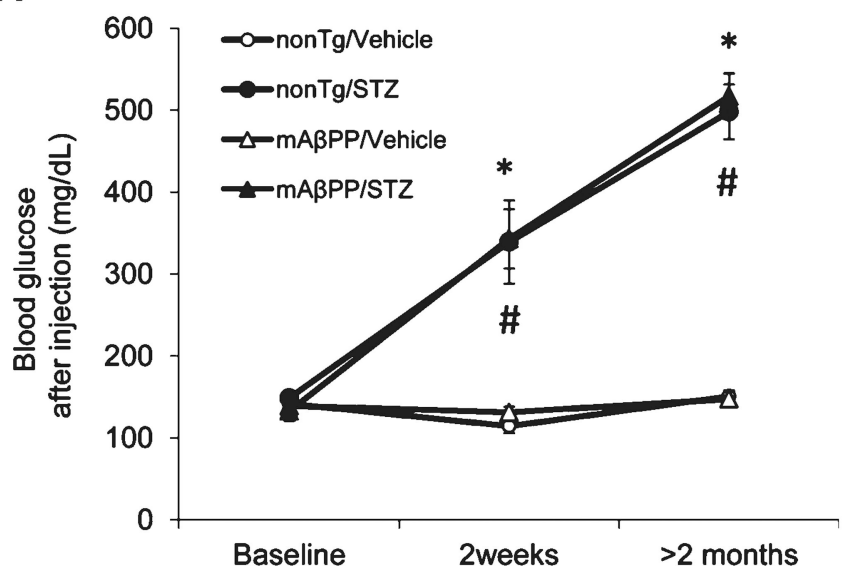

B

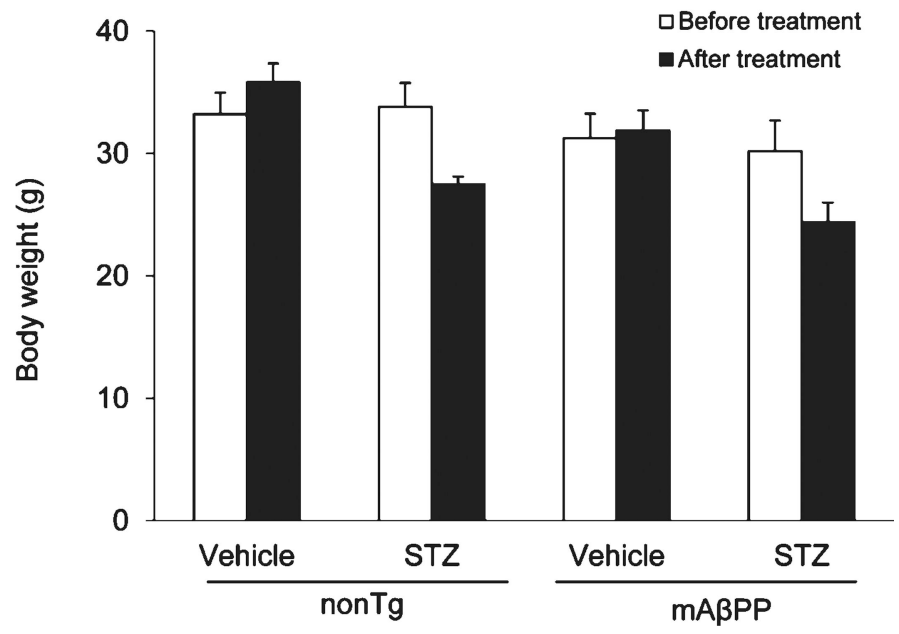

Fig. 1.

Blood glucose and body weight of vehicle-treated nontransgenic (nonTg/Vehicle), diabetic nonTg (nonTg/STZ), vehicle-treated $\mathrm{mA} \beta \mathrm{PP}$ (mA $\beta \mathrm{PP} /$ Vehicle), and diabetic $\mathrm{mA} \beta \mathrm{PP}(\mathrm{mA}$ 3PP/STZ) mice before and after induction of diabetes. A) Blood glucose levels before treatment (baseline), 2 weeks after STZ injection ( 2 weeks) and >2 months after STZ injection in the indicated groups of mice. B) Body weight changes in the indicated groups of mice before (open bar) and after 2 months of STZ treatment (Black filled bar). ${ }^{*} p<0.01$ nonTg/Vehicle versus nonTg/STZ, and \# $p<0.01 \mathrm{~mA} \beta \mathrm{PP} /$ Vehicle versus $\mathrm{mA} \beta \mathrm{PP} / \mathrm{STZ} . n=$ 5-10 per group. 


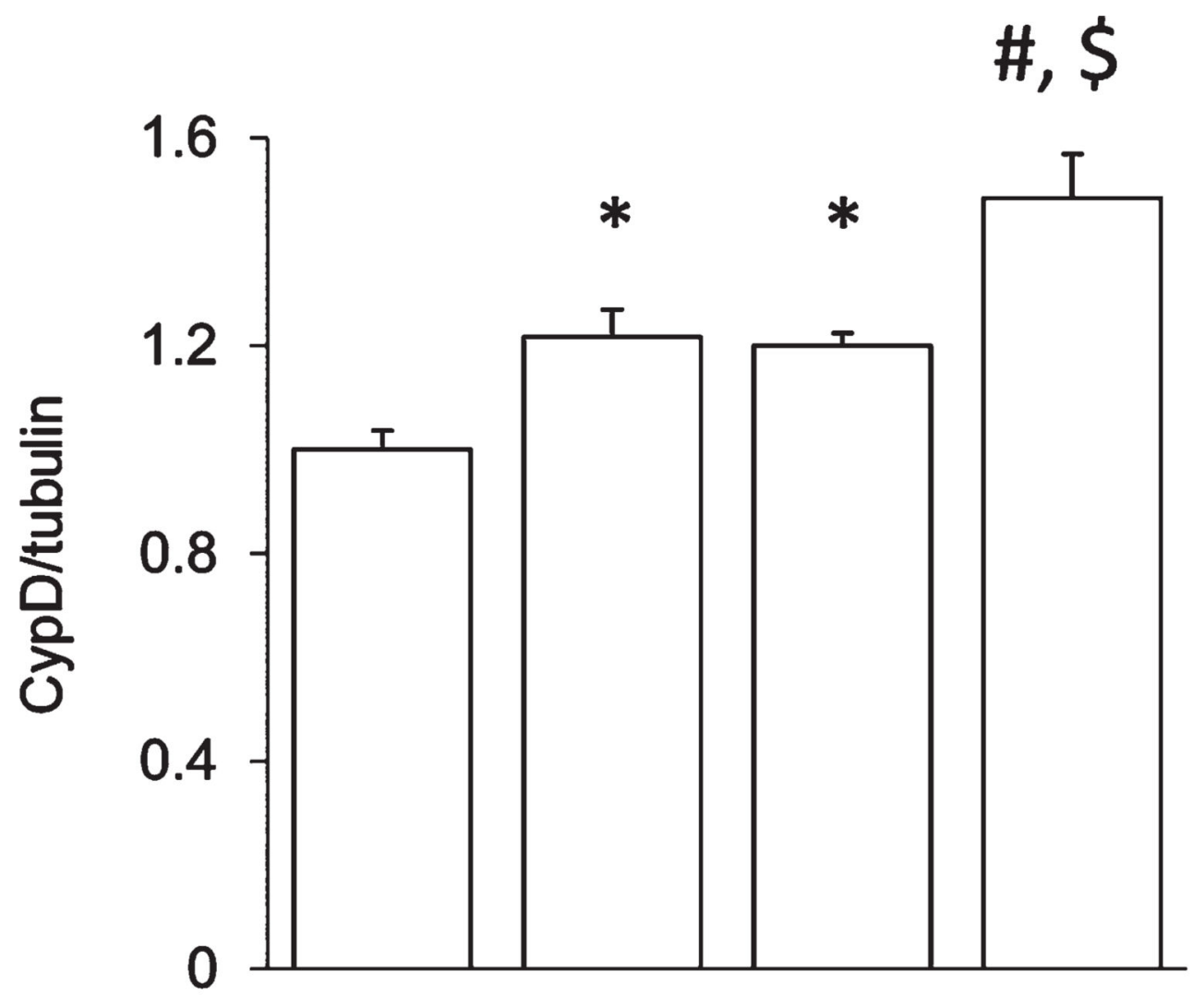

CypD

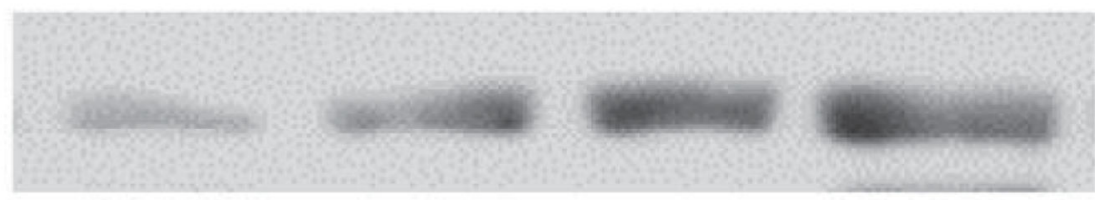

Tubulin

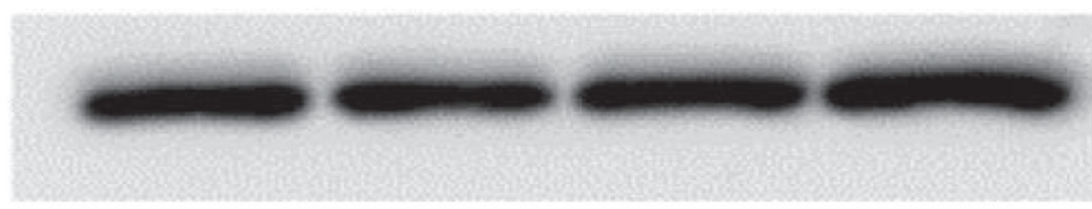

\section{Vehicle STZ Vehicle STZ nonTg \\ mABPP}

Fig. 2.

Expression of CypD in diabetic and non-diabetic nonTg and mA $\beta P P$ mice. Densitometry of CypD immunoreactive bands in the indicated groups of mice using NIH imageJ program (upper panel; $n=5$ mice per group; $p<0.05$ ). Lower panel shows representative images of immunoblots for CypD and tubulin (used as a protein loading control showing an equal amount of protein added to each lane). ${ }^{*} p<0.05$ nonTg/STZ or mA $\beta \mathrm{PP} / \mathrm{Vehicle}$ versus nonTg/Vehicle, ${ }^{\$} p<0.05 \mathrm{~mA} \beta \mathrm{PP} / \mathrm{STZ}$ versus nonTg/STZ and $\# p<0.01 \mathrm{~mA} \beta \mathrm{PP} /$ Vehicle versus $\mathrm{mA} / 3 \mathrm{PP} / \mathrm{STZ} . n=5$ mice per group. 
A B

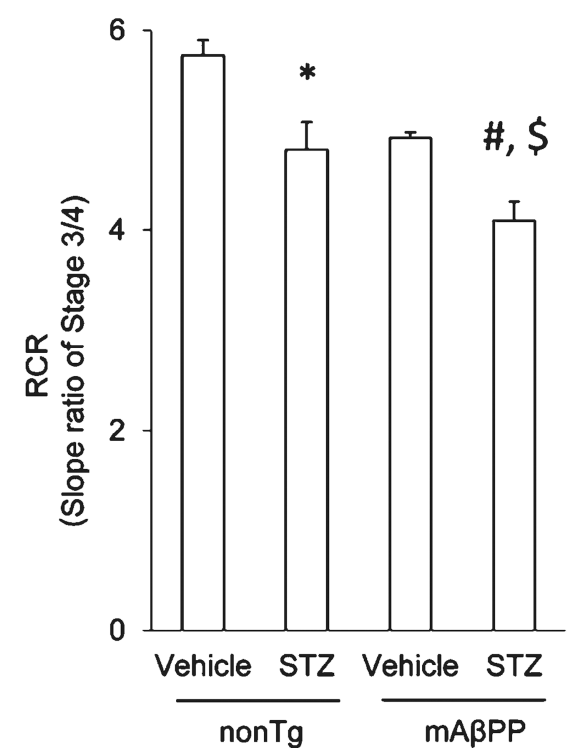

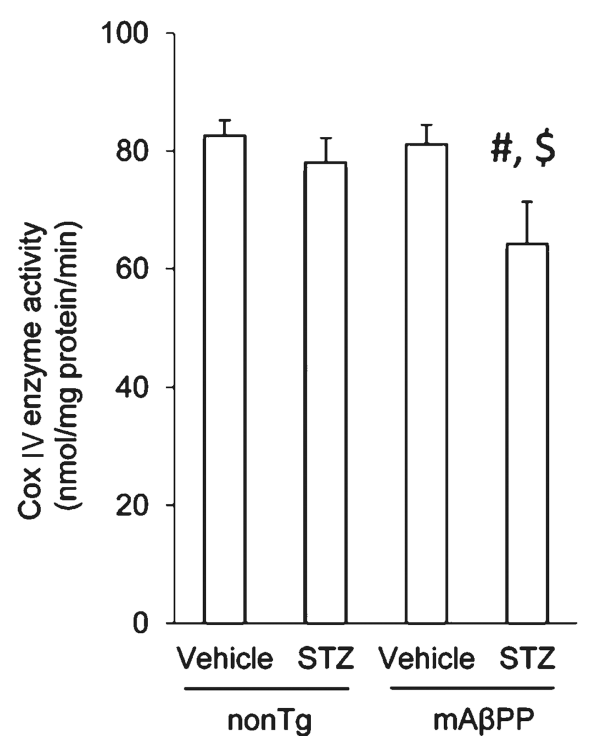

C

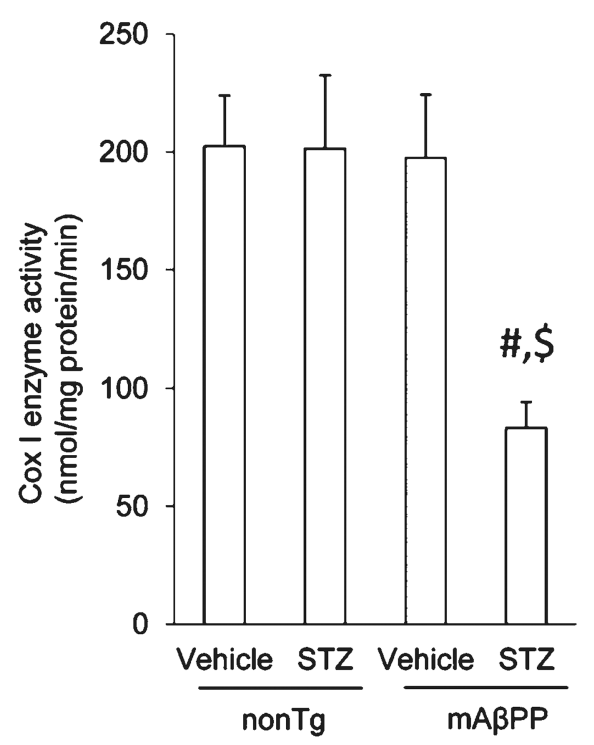

Fig. 3.

Effect of STZ-induced diabetes on mitochondrial respiratory function and complex I and IV enzyme activity in transgenic $\mathrm{mA} \beta \mathrm{PP}$ mice and nonTg littermates. Respiration control ratio (RCR) (A), cytochrome c oxidase activity (B), and NADH: ubiquinone oxidoreductase (C) in cortical mitochondria from the indicated mice at 6-7 months of age. ${ }^{*} p<0.01 \mathrm{nonTg} /$ Vehicle versus nonTg/STZ, \# $p<0.05 \mathrm{~mA} \beta \mathrm{PP} /$ Vehicle versus mA $\beta \mathrm{PP} / \mathrm{STZ}$, and ${ }^{\$} p<0.05$ $\mathrm{mA} \beta \mathrm{PP} / \mathrm{STZ}$ versus nonTg/STZ. $n=4-5$ mice per group. 

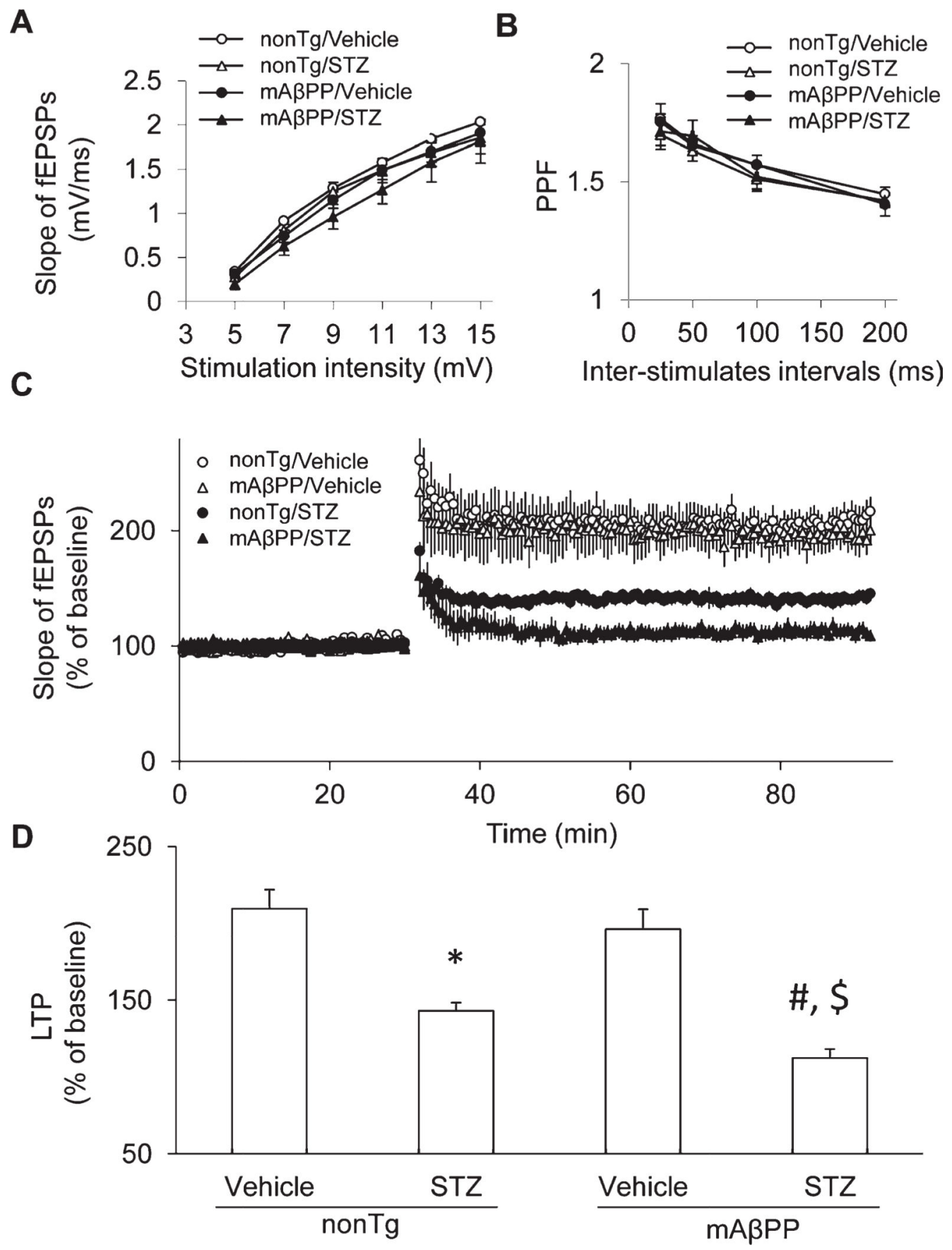

Fig. 4.

Effect of STZ-induced diabetes on basal synaptic transmission (BST), paired-pulse facilitation (PPF) and long term potentiation (LTP) in transgenic mAßPP mice and nonTg littermates. A) BST, field-excitatory post-synaptic potentials (fEPSPs) plotted against stimulation intensity; and (B) PPF, the ratio of send pulse-induced fEPSPs to the first pulseelicited fEPSPs, did not differ among indicated groups. C) Hippocampal LTP was recorded in the indicated groups for mice 6-7 months. Slices from 6-7 month-old mA $\beta P P$ mice treated with vehicle showed no significant LTP reduction compared to nonTg/Vehicle slices. 
However, experimental induction of type 1 diabetes $\mathrm{mA} \beta \mathrm{PP}$ and nonTg mice resulted in reduced impairment of hippocampal LTP. Note, LTP levels were almost completely abolished in $\mathrm{mA} \beta \mathrm{PP} / \mathrm{STZ}$ mice. D) LTP amplitudes among the indicated groups of mice were calculated by an average of fEPSP slopes during 50-60 minutes after theta burst stimulation. ${ }^{*} p<0.01$ nonTg/Vehicle versus nonTg/STZ, $\# p<0.01 \mathrm{~mA} \beta \mathrm{PP} /$ Vehicle versus $\mathrm{mA} \beta \mathrm{PP} / \mathrm{STZ}$, and $\$ p<0.05 \mathrm{~mA} \beta \mathrm{PP} / \mathrm{STZ}$ versus nonTg/STZ. $n=9-14$ per group from 5-6 mice. 
A

C

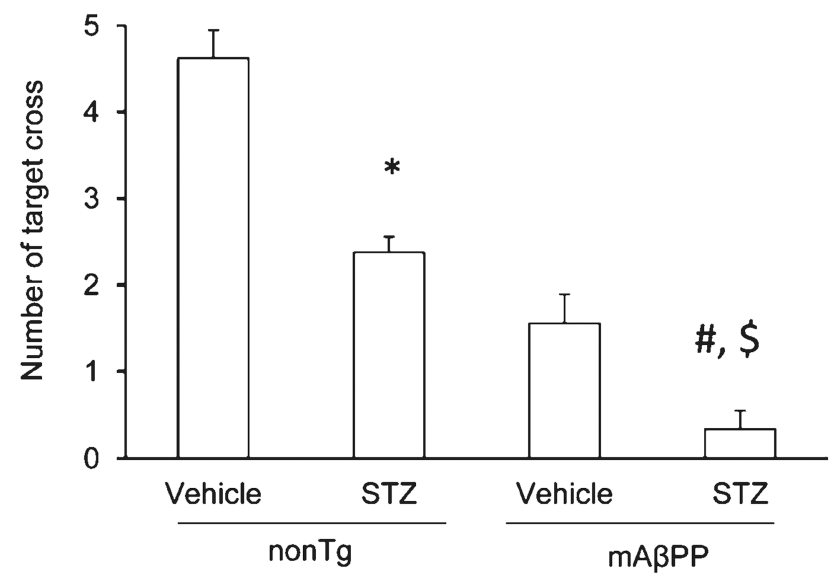

Fig. 5.
B

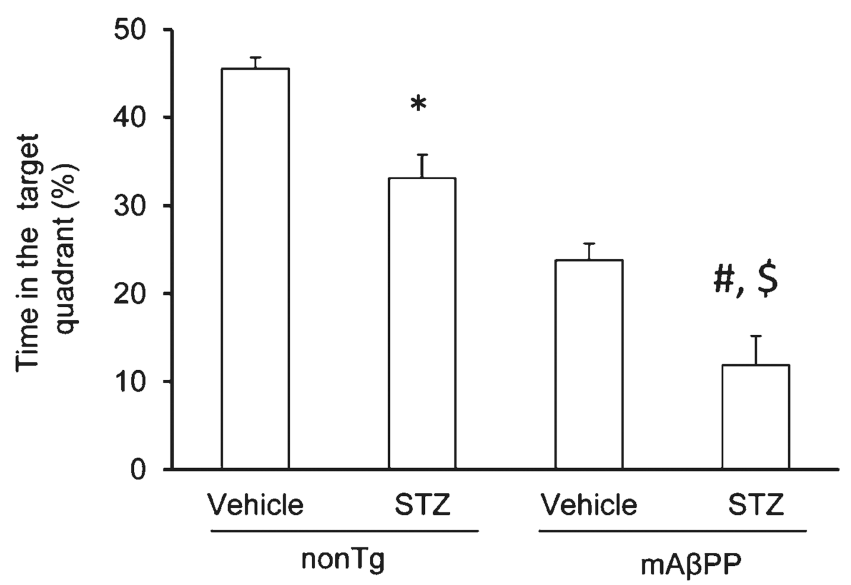

D

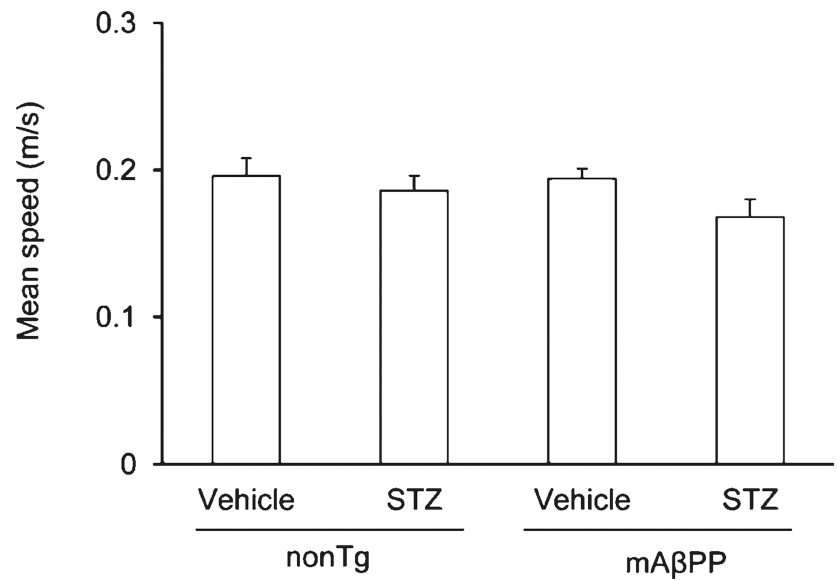

Effect of STZ-induced diabetes on spatial learning and memory in transgenic mA $\beta P P$ mice and nonTg littermates. Mice were tested in a Morris water maze at the age of 6-7 monthold. A) Escape latencies in hidden-platform during training in indicated groups. Time spent in target quadrant (B), number of annulus crossings (C), and swimming speed (D) are shown. Learning and memory are impaired in diabetic nonTg and nondiabetic mA $\beta P P$ mice. Learning and memory deficits were exacerbated in $\mathrm{mA} \beta \mathrm{PP}$ mice following induction of diabetes. "Target" indicates the area where the platform was located in the hidden-platform training session. $* p<0.01$ nonTg/Vehicle versus nonTg/STZ, $\# p<0.01 \mathrm{~mA} \beta \mathrm{PP} / \mathrm{Vehicle}$ versus $\mathrm{mA} \beta \mathrm{PP} / \mathrm{STZ}$, and ${ }^{\$} p<0.05 \mathrm{~mA} \beta \mathrm{PP} / \mathrm{STZ}$ versus nonTg/STZ. $n=6-8$ per group. 